\title{
TAKING PHILOSOPHICAL GROUNDS OF CORPORATE SOCIAL RESPONSIBILITY DEBATE SERIOUSLY
}

Seyed Mohammad Hossein Mir Mohammadi, Doctor of Philosophy, Assistant Professor of Philosophy and Applied Ethics, UGSM-Monarch Business School Switzerland,

https://orcid.org/0000-0002-5388-8109,

e-mail:mh.mirmohammadi64@gmail.com

Received: May 15, 2021

Approved for printing: May 31, 2021

Published: June 21, 2021

Mir Mohammadi, Seyed Mohammad H. (2021). Taking Philosophical Grounds of Corporate Social Responsibility Debate Seriously. Bulletin of Taras Shevchenko National University of Kyiv. Philosophy, 2(5), 37-46. https://doi.org/10.17721/2523-4064.2021/5-4/8

\section{Анотація}

Corporate Social Responsibility (CSR) is an important sphere in applied ethics. Different CSR theories have been presented during decades. Some of them are compatible with each other while some others are not. By focusing merely on the contents, it seems impossible to evaluate the different theories or to explain why different CSR theories and programs have been presented. However, this paper suggests that the variety of the debate comes from the (philosophical) grounds these theories are based. These grounds, as roots of CSR theories, can well explain, classify and evaluate different types of CSR theories. As a result of the philosophical classification and evaluation, it has been concluded that two types of CSR theories, pure and enlighten egoistic CSR, cannot be philosophically preferred. Instead, spiritual-egoistic CSR theories present better contents and programs in comparison with their rivals. Finally, as a suggestion for future investigations, it seems necessary for all CSR theories to both clarify and justify their grounds prior to presenting any other discussions.

Keywords: normative principles; pure egoism; enlightened egoism; spiritual egoism; corporate social responsibility.

\section{Introduction}

Corporate Social Responsibility known as CSR is a paradigm in which all corporations have responsibilities more than the wealth and profit for their share/stake holder. Social obligations, considering social benefits and betterment, responsibilities toward environment and so on are the examples of such responsibilities.

For decades, theorists have tried to look for CSR from different standpoints. Some viewpoints are compatible with the spirit of CSR theories while some others are completely against.

The examples of the first viewpoint can be found in K. Davis's and A. Carroll's theories. In 1973, K. Davis defined CSR as "the firm's consideration of, and response to issues beyond the narrow economic technical and legal requirements to the firm (...) [to] accomplish social benefits along with the traditional economic gains which the firm seeks" (Davis 1973, 312-3). Later in 1991, A. Carroll in his pyramid, known as The Pyramid of Corporate Social Responsibility, presented four types of responsibilities which corporations should consider: economic, legal, ethical and philanthropic responsibilities. The last responsibility refers to those spheres which improve the quality of life while the first just refers to economic needs. (Carroll 1991, 3948) Furthermore, in contemporary studies such as those done in 2007, CSR connected not only with society and its related issues but also with environment and other beings. CSR, then, is "understood to be the way firms integrate social, environment, and economic concerns into their values, culture, decision making, 
strategy and operations in a transparent and accountable manner and thereby establish better practices within the firm, create wealth, and improve society". (Berger et. al. 2007; cited from Henderson 2011, 321)

A contrary point of view can be found in theories restrict corporate responsibility to economic needs even if they are against CSR concerns, e.g. the quality of social life, environmental issues and so on. Milton Friedman's theory is the prominent example of this viewpoint. As he points out, "there is one and only one social responsibility of business - to use its resources and engage in activities designed to increase its profits so long as it stays within the rules of the game, which is to say, engages in open and free competition without deception or fraud. (Friedman, September 13, 1970)

According to mentioned contrary viewpoints, a set of fundamental questions which have either been ignored or answered poorly arise: do corporations, or in the bigger picture, economic systems have any responsibility more than maximizing the wealth for their shareholders? If so, why they have such responsibility? If corporations' responsibility has been well justified, why some theories have not defended it? Are Friedman-like viewpoints certainly wrong? If so, are all CSR programs admirable?

By focusing merely on the contents of different theories, it seems impossible to answer the mentioned fundamental questions properly.

This paper tries to explain that the mentioned different viewpoints have been affected by their different grounds. Indeed, the grounds of CSR theories play their own important role in the debate. They create their own contents and programs in CSR debate.

The grounds of CSR theories should be considered seriously. Failing to consider the grounds in the CSR debate, it seems impossible to examine and/or justify a CSR theory or a CSR-based participation. In other words, presenting new theories and programs in CSR debate, which have been admirably done during decades, is not enough to justify fundamental issues in CSR debate. Indeed, it is possible for individuals or companies to participate in a CSR program while they are acting (un)consciously against the spirit of CSR viewpoint. The reason of such paradoxes should be traced in the grounds of CSR theories, rather than their contents.

CSR grounds can affect the interpretation of CSR theories as well. As it will be discussed, it is possible to interpret a given CSR theory differently if different grounds have been considered. The outcome of such consideration can be appeared in the programs suggested by that given theory.

Therefore, paying careful attention to the grounds of CSR theories, rather than focusing merely on their contents, enables us to elaborate CSR debate. Knowing CSR grounds can help us to examine, choose or justify those theories which are compatible with the spirit of CSR viewpoint. Additionally, it enables us to interpret CSR theories with an eye to the grounds which they are based on correctly.

Accordingly, the paper has been charted as follows. In the first part, (one of) the most important ground(s) of CSR debate, named among all possible alternatives normative principles will be explained. Then, three well-known normative principles which can justify well-known CSR theories will be presented. In the second part, three types of CSR theories which are based on three different grounds will be presented. Furthermore, with an eye to the mentioned CSR grounds, the (possible) problems of each type will be investigated. In the last part, it will be explained that why only one of the mentioned ground of CSR can be preferred.

\section{Normative Principles as Grounds of CSR}

Normative Principles applied here refer to all rules accepted by individuals, communities and/or organizations ${ }^{5}$ which conduct their actions.

These principles, which can be traced in normative ethics (Frankena, 1973, 12-20), can explain why individuals, communities, and/or organizations act differently. Moreover, having a careful look on distinctions among them enables us to classify individuals, communities and organizations by their own accepted normative principles. The following examples make the statement clearer.

\footnotetext{
${ }^{1}$ The difference between a community group and an organization can be clarified as follows: the first refers to a unit with diverse memberships which share common or special values while the second refers to a unit in which members are supposed to do particular actions. Those who participate in a ceremony can be considered as a community group; and an auto-company can be considered as an organization because the auto- workers are supposed to do special tasks.
} 
Suppose that $A$, which can be an applicant for an individual, a community, an organization, always thinks how it is possible to maximize $A$ 's own wealth, power, welfare etc. $A$ also does not care about her actions' consequences. In this given context, A's normative principle is pure egoism; because a pure egoist defines acceptable actions as those that maximize particular self-interest without considering the actions' consequences. (Ferrell et. al. 2015, 157) In contrast, suppose that $B$ thinks to do only those actions which are inherently right and are in accordance with the Golden Rule ${ }^{6}$ even if they are against her self-interest. As deontology focuses on the right actions rather than evaluating their consequences (Ferrell et. al. 2015, 157), then $B$ is a deontologist.

There are different normative principles which influence people's actions. Although presenting and evaluating them is a complex task which goes beyond the scope of this paper, three of them, i.e., pure egoism, enlightened egoism and spiritual egoism, will be discussed. For they can be considered as the grounds that wellknown CSR theories are based on.

\section{Pure Egoism}

In philosophical literature, ethical egoism is a normative principle which "holds that one is always to do what will promote his own greatest good -- that an act or rule of action is right if and only if it promotes at least as great a balance of good over evil for him in the long run as any alternative would, and wrong if it does not."(Frankena 1973, 15)

Accordingly, a pure-egoistic individual, community and/or organization holds that the right is an act or a rule which promotes at least the greatest balance of good over evil for themselves in the long run as any alternative would, and wrong if it does not.

The point which is vital to be considered in this normative principle is the fact that an action is right if and only if it promotes the greatest balance of good over evil for the particular agent. For example, if the action $p$, no matter what it is, promotes the greater balance of good over evil for the agent $\mathrm{P}$, then $p$ is good. Simultaneously, if the agent $\mathrm{P}$ evaluates the action $p$ somewhere else in a way which cannot promote the greatest good over evil, then $p$ is wrong.

Suppose, then, that the agent $\mathrm{P}$ is trying to participate in a CSR program. For example, she wants to participate in a Carroll-pyramid-based program which contributes the resources to the community and improves the quality of life. As $\mathrm{P}$ is a pure egoist, she will not participate in such a program unless it promotes the greatest balance of good over evil for herself.

\section{Enlightened Egoism}

Pure egoism, as explained above, focuses on the one's own long-term greatest good without considering others'. However, enlightened egoism is a principle which takes "a long-range perspective and allow for the well-being of others although [the agent's] own self-interest remains paramount". (Ferrell et. al. 2015, 158)

The example of a situation in which this normative principle influences the action can be found in circumstances in which people help the needy only because of getting rid of their unpleasant feeling.

The most important point in this ground is the fact that ultimate self-interest should remain in all cases paramount. Indeed, this ground allows individuals, communities and/or organizations to participate in programs which consider others' well-being. However, this participation is completely conditional. It means that those programs which finally fulfill the self-interest of individuals, communities and organizations will be considered as good.

On the contrary, programs and actions which do finally not fulfill self-interest shall be considered as wrong. For example, deception is wrong because it does finally not fulfill individuals', communities' and/or organizations' self-interest: if they deceive others, others will be inclined to deceive them. As being deceived by others is against the ultimate self-interest of individuals, communities and/or organizations, then participating in programs which deceive others forbidden.

So, with an eye to the well-known philosophical distinction between intrinsic and instrumental good $(\text { evil })^{7}$, it is obvious that enlightened egoism never considers, or believes in, intrinsic good (evil) programs and

\footnotetext{
${ }^{2}$ The Golden Rule refers to a well-known ethical rule which states: Treat others as you want to be treated.

${ }^{3}$ In contemporary philosophical term, "something is intrinsically good if it worth having for its own sake". However, something is instrumentally good if, while not necessarily being good in itself, it leads to goodness". (Palmer 1991, 37)
} 
actions. If so, one program can be considered good, in a given context, while that very program is forbidden in another.

As it is obvious, there is no universal or formal rule to evaluate actions in this ground. All enlightenedegoistic programs and actions can be considered good or bad. The evaluation is directly connected to the amount of ultimate self-interest. We will return to this point once again.

\section{Spiritual Egoism}

Spiritual egoism, as the third principle presented here, is a spiritual-philosophical ground which allows for others' well-being gained by the intrinsic right and $\operatorname{good}^{8}$ actions. Moreover, the end and means will be both considered in evaluations.

Spiritual egoism is based on a rich anthropology. Spirit, from the philosophical-anthropological standpoint, has been considered as the essence of ego. In contrast with its rivals, i.e., pure and enlightened egoism, ego in this ground can detach from the material world and obtains a non-material insight.

According to philosophical-anthropological heritage, spirit in this ground has an important role to play. Although these characters of spirit as well as spiritual egoism can be traced in philosophical writings, e.g. in M. Scheler's (1874-1928) philosophical anthropology, some CSR theories have been based on them. (Scheler 1973, 371; Naughton 2006, 40) Relaying on philosophical findings, it is possible to present at least four characteristics for spirit. Consequently, spiritual egoism is of special characters.

First, spirit in this ground is open to the world. Second, it is a pure actual entity rather than a substantial thing or concrete entity. Third, it is through spirit that human beings are able to go beyond the material world, e.g. the phenomenological intuition of essences, Absolute Being and so on. Finally, the spiritual center of action, as a vital center, has consciousness of itself.

Accordingly, spiritual egoism, as a ground of some CSR theories, is able to go beyond the materialistic viewpoint. This new standpoint helps spiritual egoism achieve a new insight, identify non-martial values and connect them to the material world. Considering these characters, it is essential to know why some contemporary CSR theories and models have been presented.

\section{Pure-egoistic CSR and Its Problems}

Pure-egoistic CSR refers to those theories which are based on pure egoism and restrict the responsibility of an individual, a community's members and an organization's manager(s) to maximize wealth, welfare etc. for herself, its members and its shareholders respectively. Indeed, there is no obligation for them except maximizing their own wealth, welfare etc.

The first part of Friedman's theory ${ }^{9}$ is a prominent example of this viewpoint in CSR. According to Friedman's doctrine which highly emphasizes that "the social responsibility of business is to increase its profits" (Friedman, September 13, 1970), the corporations have no obligation to consider others or consequences of their activities.

The first problem of pure-egoistic CSR is the fact that it is inherently paradoxical. In the interest of knowing its paradox, let's first return to pure-egoism's philosophical paradox mentioned in ethical literature. Then it will be applied in pure-egoistic-CSR doctrine as well.

As W. K. Frankena explains, "[pure egoism] holds (1) that an individual's one and only basic obligation is to promote for himself the greatest possible balance of good over evil. What is not so clear is what the ethical egoist says about the individual as a moral spectator, adviser, or judge. He may say (2) that even in making second- and third-person moral judgments an individual should go by what is to his own advantage,

${ }^{4}$ The right and the good here refer to all actions which are not evaluated as right and good by considering their consequences. Instead, the action is right and good if it follows the inherent right and good standard, such as Moral Law, Gulden Rule and so on. (cf. Ross, 1930; Kant, 1889; Scheler, 1973)

${ }^{5}$ As it is obvious, Friedman's theory has two parts. The first part, which can be named positive part of his theory, refers to those actions which increase the corporations' profits. The second part, named as negative part, refers to those actions which should not be done by corporations such as deceiving others. This classification helps us to evaluate each part of his theory separately. 
or (3) that in making such judgments an individual should go by what is to the advantage of the person he is talking to or about. Tenet (3), however, seems to be inconsistent with the spirit of ethical egoism, unless it is based on the premise that judging as it prescribes is to the individual's own advantage, in which case (3) falls under (2). Hence I shall take an ethical egoist to be asserting tenets (1) and (2)". (Frankena 1973, 18)

Accordingly, it is not obvious whether a pure-egoistic CSR theorist, who is defending her theory, presents her idea in accordance with her self-interest or not. If she believes on pure-egoistic CSR theory, she should follow the exact obligation, i.e., promoting the greatest good over evil for herself, her community or her organization while she is presenting her theory. If so, she may present her theory to deceive others. Conflict-of-interest contexts, e.g. when others' promoting profits does not lead to her profit, is an outstanding example in which she should deceive others; because she should act in a way that promotes the good for herself, her community and/or organization. Conversely, if she herself does not believe her pure-egoistic CSR theory, particularly in situations she is an adviser, she herself accepts that her theory does not have generality which is a necessary condition for her universal theory.

Similarly, Friedman's theory contains this paradox. Indeed, he may supposedly suggest his theory to deceive others because his end is to increase (his) business profits. If not, he, as an adviser, holds that his theory does not have generality. It means that his theory in some situations, such as being an adviser, works wrongly.

As the second problem, the application of CSR theories, whatever they are, is completely doubtful when pure egoism is the ground. For example, suppose that (1) $A$ is an organization which mindfully accepts pure egoism as its normative principle; and (2) wants to apply the very CSR theory which states that "the fundamental idea of corporate social responsibility is that business corporations have an obligation to work for the social betterment" (Fredrick 1986). In this case, the CSR theory will be completely applied by $A$ if and only if it promotes the greatest balance of good over evil.

What is not so clear is the application of this CSR theory in contexts of moral conflicts. If this CSR theory insists on the activity, e.g. a philanthropic activity, which never promotes the greatest good over evil for $A$ although it works for the social betterment, then $A$ may probably not participate in the activity. As another example, suppose that the program $a$ is a Friedman-based activity which can promote the greatest good over evil for the given organization $A$. However, it cannot promote the greatest good over evil for its contemporary shareholders. In this context, the application of program $a$ will be completely vague. So, if this normative principle be a ground of CSR theories, then the application of them, no matter what they are, will be completely vague.

Furthermore, pure egoistic individuals, communities and organizations will wrap CSR theories. Pure egoism as a ground is in contrast with contemporary understanding the concept of responsibility in CSR. As it has been mentioned, the CSR theories have been presented to highlight that the responsibility of the individual, community and organization have not been restricted to themselves while pure egoism suggests conversely. So it is obvious that those CSR theories which do not follow the pure-egoism evaluation, e.g. those which are in contrast with the individuals', communities' and/or organizations' long run benefits, will not be applied by pure egoistic individuals, communities and/or organizations.

Therefore, pure egoism is weaker than what can be accepted as an appropriate ground of CSR theories. It contains a paradox; it never protects the application of CSR programs; and it is not compatible with contemporary understanding of CSR.

Does the enlightened-egoistic CSR have a better philosophical place? The following part will answer the question.

\section{Enlightened-egoistic CSR and Its Problems}

Enlightened-egoistic CSR refers to those theories which care only about the ultimate self-interest. It means that the end, rather than the means, is of importance.

Moral activities as well as suggestions in this type of CSR theories are acceptable. As "enlightened [egoism as a ground] may abide by professional codes of ethics, control pollution, avoid cheating on taxes, help create jobs, and support community projects" (Ferrell et. al. 2015, 158-9), then enlightened-egoistic CSR theories can suggest moral programs such as controlling pollution, avoiding cheating on taxes and so on. 
As it has been mentioned earlier, it is vital to consider that the mentioned programs will be highlighted by enlightened-egoistic CSR theories "not because these actions benefit others but because they help achieve some ultimate [egoistic] goal" (Ferrell et. al. 2015, 159). Accordingly, enlightened-egoistic individuals, communities and/or organizations will participate in activities that help them achieve their ultimate egoistic goals. However, participating in programs which do finally not fulfill the ultimate self-interest of an individual, a community and an organization is forbidden.

The second part of Friedman's theory is an eminent example of this type of CSR. According to his theory, deception and fraud are forbidden for businesses. Based on enlightened-egoism, they are forbidden not because deception and fraud are inherently evil but because they are against the ultimate egoistic goals. Because the ultimate self-interest of an individual, a community and an organization will not remain paramount in actions such as deception or fraud. They are forbidden in all enlightened-egoistic CSR.

It seems that enlightened egoism, contrary to pure egoism, is compatible with CSR theories. As (1) CSR theories try to encourage companies to do ethical-social actions; and (2) enlightened egoism, which cares about the end, can provide programs which are compatible with the ethical-social actions; then, the conclusion will be reached to (3) enlightened egoism is an acceptable ground for CSR theories.

However, this principle, which may justify some ethical actions, can be thread for CSR theories. It changes CSR theories to instruments which help the individuals, communications and/or organizations achieve their own interests. As tenet (2) implies, an enlightened-egoist never considers others' benefit at all while her ultimate individual goal, as her end, should remain paramount. If so, the mentioned, ethical actions are not important for enlightened-egoists.

Enlightened egoism cannot facilitate the application of CSR theories either. Instead, it is a ground which provides situations for individuals, communities and/or organizations to escape from CSR's duties. This phenomenon can be named CSR disengagement.

The phenomenon of CSR disengagement supported by enlightened egoism can be considered as thread for all CSR debates. To know what the concept refers to, let's start with a given context in which a CSRdisengagement phenomenon occurs:

Suppose that $A$, which is an applicant for an individual, a community or an organization, lives in a decade with a widespread "perception that population growth and consumption are challenging the ability of Earth's ecosystems to provide for future generations and that the response to this challenge requires more than "place-based" (...) conservation or the control of environmental pollutants." (Committee on Incorporating Sustainability in the U.S. Environmental Protection Agency 2011, 16)

The phenomenon of CSR disengagement occurs when $A$ states:

$A$ 's overall well-being is difficult to negotiate. There are necessities, such as cultural, economic etc., which do not allow $A$ to follow the place-based conservation or the control of environmental pollutants.

CSR disengagement is a phenomenon in which the individual, community and organization, directly or indirectly, escapes from participating in (some) CSR programs. This phenomenon, which can be coincided with, or justified by, a set of statistical analyses, reasons, theories etc., implies that CSR programs are not of ethical necessity.

Relying on the findings of moral disengagement presented by Albert Bandura (1996), it is possible to consider CSR disengagement as a mechanism which converts harmful acts to harmless ones. Similar to moral disengagement, the outcome of CSR disengagement might then be "displacement of responsibility, misrepresenting or disregarding the injurious effects inflicted on others, and vilifying the recipients of maltreatment by blaming and dehumanizing them."(Bandura 1996, 364)

It is highly predictable that the phenomenon of CSR disengagement occurs in the conflict of interests; when the individual, community and organization sacrifices CSR programs because of obtaining some other interests. 


\section{Spiritual-egoistic CSR and Its Probable Problem}

This type of CSR refers to all debates which encourage individuals, communities and/or organizations to go beyond their materialistic understanding firstly, and present non-material meanings of responsibility, society, wealth, welfare and so on, secondly.

This type of CSR theoy insists that if the spirit is an essential part of human beings, as it is, then it should be considered as a sphere which corporations are responsible for. Indeed, they are responsible for human beings as a spiritual being rather than an animal-like being. If so, spiritual needs of individuals, communities and/or organizations should be also taken into account.

Religion-based CSR is an example of those theories which have been based on spiritual egoism. This type of CSR theory holds that it is necessary for organizations to improve their understanding about their customers' need and wants. They insist that "in order for an organization to identify and deliver a customer's need or want, a high degree of creativity, insight, coordination, effort, and ongoing development marshaled on sustained basis toward understanding the customer and the market is necessary". (Naughton 2006, 54; see also Novak 1990)

In spiritual-egoistic models of CSR, the corporation sees itself in others. So, maximizing the wealth for the corporations means increasing the profits for not only other corporations but also those who will be affected by it.

As spirit has its own characteristics, it is possible for it to be connected with non-material world. Therefore, the dualities among shareholder and stakeholder, human beings and environment and so on will be completely removed.

The spiritual-egoistic CSR theories never restrict the needs to material ones. According to these theories, "the business organization cannot be confined to only financial transactions and self-interest calculations precisely because it is so difficult for people to develop within such a business"; because "[human beings] bring [their] whole selves to work, both body and soul". (Paulus PP. II 1981, Article 24)

In spiritual-egoistic CSR, society works as a whole. It means that the corporation should be considered as a community of work. (Naughton 2006, 33) So, it is impossible, in spiritual-egoistic CSR, to hold that the corporation is not responsible for social betterment. For the defeat of the society is the defeat of the corporation.

This ground may face a probable problem. The spiritual-egoistic CSR may neglect the fact that there are special responsibilities which should be considered by individuals, communities and/or organizations.

Special responsibilities, which is well-known in moral-philosophical writings as "the problem of special responsibilities" (Palmer 1991, 88-9), states that people's intuition or common belief testifies that there are special responsibilities. Indeed, "most of us accept that we have special responsibilities to particular people". (Palmer 1991, 88) For example, most people accept that "a teacher has a special obligation to her students" (Palmer 1991, 89). If so, although the teacher as a spiritual egoist is responsible to all, she has a special obligation to her students. Accordingly, spiritual-egoism as a ground for CSR may neglect this ethical responsibility. Clearly, the corporations have special responsibilities to particular people although they are responsible to all people.

\section{Which One Can Be Preferred: Pure-egoistic, Enlighten-egoistic or Spiritual-egoistic CSR?}

As it has been mentioned, there are at least three different grounds which CSR theories are based on. These grounds affect the CSR contents and programs. Also, each type of CSR has its own (probable) problems. If so, how is it possible to choose one of them? What follows is an attempt to investigate the answer.

To find which ground is finally compatible with CSR concerns, let us start with a statement, mentioned by Frankena, which has admirably summarized the duty of contemporary ethics:

If our morality is to be more than a conformity to internalized rules and principles, if it is to include and rest on an understanding of the point of these rules and principles, and certainly if it is to 
involve being a certain kind of person and not merely doing certain kinds of things, then we must somehow attain and develop an ability to be aware of others as persons, as important to themselves as we are to ourselves, and to have a lively and sympathetic representation in imagination of their interests and of the effects of our actions on their lives. The need for this is particularly stressed by Josiah Royce and William James. Both men point out how we usually go our own busy and selfconcerned ways, with only an external awareness of the presence of others, much as if they were things, and without any realization of their inner and peculiar worlds of personal experience; and both emphasize the need and the possibility of a 'higher vision of an inner significance' which pierces this 'certain blindness in human beings' and enables us to realize the existence of others in a wholly different way, as we do our own. (Frankena, 1973, 69)

Contrary to our moral duty, both pure and enlightened-egoistic CSR support programs, which contain certain blindness in human beings. For they emphasize that "self-interest" should be finally fulfilled.

As moral-psychological findings also suggest, moral growth cannot be promoted by theories based on pure and enlightened egoism. Recall Lawrence Kohlberg's doctrine, as an example, which implies that cognitive moral development cannot be promoted by self-interest orientations. As his theory explains, moral development is of six stages as well as six orientations. In his system, they have been ranked from the lowest to the highest as follows: obedience and punishment orientation; self-interest orientation; interpersonal accord and conformity orientation; authority and social-order maintaining orientation; social contract orientation and universal-ethical-principles orientation. (Ferrell et. al. 2015, 169-70) It is obvious that each stage of moral development affects the moral attitudes, values and concerns. So, CSR theories which have been based on self-interest orientation put their followers in a low stage of moral development.

There is a connection between the stage of moral development and the stage of values as well. As it can be traced in philosophical anthropology, low stages of moral development can create low stages of values.

The concept of "low" and "high" values, borrowed here form Max Scheler's philosophical anthropology, implies that there is a rank of values. As Scheler's doctrine indicates, there is an objective order of value types. This rank of values from the lowest to the highest are as follows: pleasure, utility, vitality, culture, and holiness. "Claiming that there is an objective order of values (...) necessarily entails that the higher values "ought" to be preferred to the lower (...)". (Davis and Steinboch, 2018) But pure and enlightened egoistic CSR, which will be conducted by self-interest orientation, cannot create the mentioned high-level values.

If so, spiritual egoism, as a ground of CSR theories, can be preferred because there is no paradox in it; and it never supports any CSR disengagement. Additionally, as spirit in this ground can go beyond the selfinterest orientation, it can suggest programs which contain higher values as well as promote the moral growth.

\section{Conclusion}

For decades, the debate related to Corporate Social Responsibility (CSR) has been completely improved. However, there are fundamental problems which cannot be properly answered by focusing only on CSR contents. This paper suggested that the CSR theories are based on (philosophical) grounds. These grounds of CSR, which can be named as normative principles, affect CSR theories. Also, they can explain the diversity, classify the contents as well as evaluate CSR theories philosophically. Pure egoism, enlightened egoism and spiritual egoism have been considered here as grounds that well-known CSR theories are based on. The mentioned grounds can classify CSR theories into three types. As there are philosophical problems in two grounds of CSR theories, i.e., pure-egoism and enlightened egoism, it has been concluded that two types of CSR theories cannot be preferred. As such, spiritual-egoistic CSR can suggest better theories and programs in comparison with its rivals. 


\section{Acknowledgment}

I would like to express my deepest appreciation to all those who provided me the possibility to complete my academic journey from BA to post-doc program. I appreciate my colleagues at UGSM-Monarch Business School Switzerland who have highly encouraged me to invite philosophy to business spheres. A special gratitude I give to my post-doc supervisor, Dr. J. Henderson, whose contribution in stimulating suggestions and encouragement helped me to complete this manuscript. Furthermore, I would also like to acknowledge with much appreciation to Dr. D. Bevan and Dr. N. Madarasz for sharing their pearls of wisdom with me during the course of this research.

\section{References}

Bandura, Albert. (1996). Mechanisms of Moral Disengagement in the Exercise of Moral Agency. In Journal of Personality and Social Psychology 1996, Vol. 71, No. 2: 364-74.

Berger, Ida E., Peggy H. Cunningham and Minette E. Drumwright. (2007). Mainstreaming Corporate Social Responsibility: Developing Markets for Virtue. California Management Review, Vol. 49, No. 4, (Summer 2007):132-157

Carroll, Archie B. (1991). The pyramid of corporate social responsibility: Toward the moral management of organizational stakeholders. Business Horizons, Volume 34, Issue 4, 1991: 39-48.

Committee on Incorporating Sustainability in the U.S. Environmental Protection Agency, Science and Technology for Sustainability Program Policy and Global Affairs Division and National Research Council of the National Academies. (2011). Sustainability and the U.S. EPA, Washington D. C.: The National Academies Press.

Davis, K. (1973). The Case for and against Business Assumption of Social Responsibilities. The Academy of Management Journal, 16(2), 312-322. https://doi.org/10.2307/255331

Davis, Zachary and Anthony Steinbock, (2018). Max Scheler. In The Stanford Encyclopedia of Philosophy (Winter 2018 Edition), Edward <https://plato.standford.edu/archieves/win2018/entries/scheler/>.

Ferrell, O. C., John Fraedrich, and Linda Ferrell. (2015). Business Ethics: Ethical Decision Making and Cases. USA: South-Western Cengage Learning.

Frankena W. K. (1973(second ed.)). Ethics. New Jersey: Prentice-Hall.

Friedman, Milton. (1970). A Friedman doctrine- The Social Responsibility of Business Is to Increase Its Profits. In New York Times, September 13, 1970. https://www.nytimes.com/1970/09/13/archives/afriedman-doctrine-the-social-responsibility-of-business-is-to.html

Henderson, Jeffery. (2011). Global Citizenship Examined: A Methodology of the New Triad Model. PhD diss., UGSM-Monarch Business School Switzerland.

Kant, Immanuel. (1889). "The Critique of Practical Reason" in Kant's Critique of Practical Reason, etc. Translated by Thomas Kingsmill Abbot. London: Longmans, Green \& Co., Paternoster-Row.

Naughton, Michael. (2006). The Corporation as a community of work: Understanding the Firm within the Catholic Social Tradition. In Ave Maria Law Review 4:1 (4 2006): 33-47.

Novak, M. (1981 (rev. ed. 1990)). Toward a Theology of the Corporation, Washington D. C.: The AEI Press.

Palmer, Michele. (1991). Moral Problems: A Course Book. Canada: University of Toronto Press; Toronto Buffalo.

Paulus PP. II, Iaonnes. (1981). Laborem exercens. Rome: Vatican

Ross, W.D. (1930). The Right and the Good, Oxford: Clarendon Press.

Scheler, Max. (1973). Formalism in Ethics and Non-Formal Ethics of Values. Translated by Manfred S. Frings and Roger L. Funk. Evatson. Northwestern University Press. 


\section{СЕРЙОЗНО СПРИЙМАТИ ФІЛОСОФСЬКІ ОСНОВИ КОРПОРАТИВНОЇ СОЦІАЛЬНОЇ ВІДПОВІДАЛЬНОСТІ}

Сейєд Мохаммад Хоссейн Мір Мохаммаді, доктор філософії, асистент кафедри філософії та прикладної етики, UGSM-Monarch Business School Switzerland, https://orcid.org/0000-0002-5388-8109, e-mail:mh64@mirmohammadi.com.

\section{Анотація}

Корпоративна соціальна відповідальність (КСВ) є важливою сферою прикладної етики. Протягом десятиліть були представлені різні теорії КСВ. Деякі з них сумісні один з одним, а деякі ні. Зосереджуючись лише на змісті, здається неможливим оцінити різні теорії чи пояснити, чому були представлені різні теорії та програми КСВ. Однак ия стаття припускає, що різноманітність дискусій походить від (філософських) підстав, на яких базуються иі теорії. Ці підстави, як коріння теорій КСВ, можуть добре пояснити, класифікувати та очінити різні типи теорій КСВ. У результаті філософської класифікації та очінки було зроблено висновок, що не можна філософськи віддавати перевагу двом типам теорій КСВ, чистій та просвітнищькій егоїстичній КСВ. Натомість духовно-егоїстичні теоріі КСВ представляють кращий зміст і програми в порівнянні зі своїми суперниками. Нарешті, як пропозиція для майбутніх досліджень, видається необхідним, щоб усі теорії КСВ як прояснили, так $i$ обгрунтували свої підстави, перш ніж представляти будь-які інші обговорення.

Ключові слова: нормативні принципи; чистий егойзм; просвітлений егойзм; духовний егойзм; корпоративна сочіальна відповідальність.

Отримано: 15.05 .2021

Ухвалено до друку: 31.05 .2021

Опубліковано: 21.06 .2021

Мір Мохаммаді, Сейєд Мохаммад Х. (2021). Серйозно сприймати філософські основи корпоративної соціальної відповідальності. Вісник Київського начіонального університету імені Тараса Шевченка. Філософія, 2(5), 37-46. https://doi.org/10.17721/2523-4064.2021/5-4/8 